\title{
How plant Immune System Works?
}

ISSN: 2637-7659

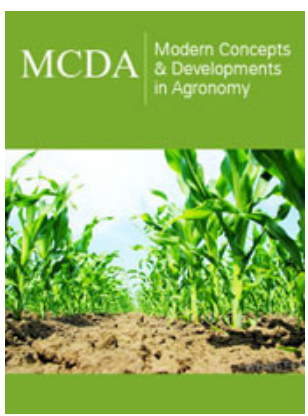

*Corresponding author: Deyala M Naguib, Botany and Microbiology Department, Faculty of Science, Zagazig University, Zagazig, Egypt

Submission: 觜 August 03, 2019

Published: 温January 07, 2020

Volume 5 - Issue 4

How to cite this article: Deyala M N. How plant Immune System Works?. Mod Concep Dev Agrono.5(4). MCDA.000617.2020. DOI: 10.31031/MCDA.2020.05.000617

Copyright@ Deyala M Naguib, This article is distributed under the terms of the Creative Commons Attribution 4.0 International License, which permits unrestricted use and redistribution provided that the original author and source are credited.

\author{
Deyala M Naguib* \\ ${ }^{1}$ Botany and Microbiology Department, Faculty of Science, Zagazig University, Zagazig, Egypt \\ ${ }^{2}$ Biology Department, Faculty of Arts and Science in Qilwah, Baha University, Qilwah, KSA
}

\begin{abstract}
Plant diseases have major effects on agricultural production and the food supply. Currently, worldwide crop losses due to disease are estimated to exceed hundreds billion dollars. Although application of fungicides and pesticides has helped control plant diseases, chemical control is economically costly as well as environmentally undesirable. Therefore, the development of new strategies based on a plant's own defense mechanisms for disease control is critical for sustaining agricultural production and improving our environment and health. From this point of view this review how plant immune system work against pathogen?
\end{abstract}

Keywords: Defense genes; Elictors; Induced defense; Reactive oxygen species; Signal Transduction

\section{Introduction}

Phyto-pathogenesis is a global problem, posing a serious threat to food security. One of the major challenges for a very rapidly growing world population is the need to meet up the demand for adequate food supply. This requires ecologically sound, compatible strategies in agriculture for sustainable crop production. However emerging and re-emerging plant diseases continuously challenge this ability; consequently, the control of plant diseases continues to be an uphill task [1]. Plant diseases have major effects on agricultural production and the food supply. Currently, worldwide crop losses due to disease are estimated to exceed hundreds billion dollars. Although application of fungicides and pesticides has helped control plant diseases, chemical control is economically costly as well as environmentally undesirable. Therefore, the development of new strategies based on a plant's own defense mechanisms for disease control is critical for sustaining agricultural production and improving our environment and health. From this point of view this review how plant immune system work against pathogen?

\section{How plants identify different parasites}

For plants to effectively control invading pathogens, they must recognize such pathogens as foreign non-host components. Thus, they have evolved very effective signaling mechanisms that help them in microbial pathogens detection. Pathogen recognition is often detected after the perception of intruding microbes or their products by microbe or pathogen associated molecular patterns (MAMPs or PAMPs). These are certain class of plasma membrane bound extracellular receptors. These can recognize microbial elicitors. In the presence of MAMPs, PRPs are activated leading to production of active defense responses against these pathogens. This ensures that the would-be pathogens are stopped before they could cause any serious infection in the plant [2].

\section{Signal transmission in the plant immune response}

Pathogens are recognized by perception of elicitors through the receptors that are either located on the plasma membrane or in the cytosol. A signal transduction chain is initiated after binding of the elicitor ligand to its receptor. In turn these signal messenger molecules activate the transcription factors regulating plant defense gene expression [3]. 


\section{Defense signaling regulatory compounds}

These are the molecules sharing in transduction the effect of the elicitors to the whole plant cellular system. These are such as:

Calcium and ion channels: The earliest reactions of plant cells to elicitors lead to changes in plasma membrane permeability leading to influx of calcium and proton, and efflux of potassium and chloride. These ion fluxes are necessary for the oxidative burst induction, defense gene activation and phytoalexin production. Plasma membrane-located ion channel open as a result of binding the elicitor to its receptor which stimulate elevated cytosolic calcium levels, as well as activate additional ion channels and pumps that cause the other ion fluxes observed [4].

Protein kinases: Many evidences and in vivo phosphorylation data suggest that phosphorylation cascades are involved in defense signaling at many different levels. protein kinases activate downstream signaling elements through phosphorylation [2].

Reactive oxygen species: Elicitor-mediated calcium influx, as well as transient elevation of cytosolic calcium levels which stimulate the accumulation of reactive oxygen species (ROS), such as superoxide, hydrogen peroxide and hydroxyl free radical. ROS is a central component of the plants defense machinery. ROS act as direct toxic substances to pathogens, catalyze the defense physical barriers and are involved in signaling the defense reactions, such as phytoalexin synthesis and defense gene activation, programmed cell death [4].

Ethylene: The simplest hormone in plants is the gaseous ethylene. It is involved in various developmental processes, such as plant growth and fruit ripening. Besides these processes, it is also involved in environmental stress signaling upon wounding or pathogen attack [5].

\section{Transcription factors regulating plant defense gene expression}

Transcription factors are defined as transcriptional regulators that function by binding to specific cis-regulatory elements present in the promoters of target genes [6].

\section{Plant Response to Pathogens}

Plant responses to the presence of pathogens involve biochemical, cellular level defenses and defenses at tissue level. The ability of plant to mount an active defense response is under genomic control [7]. These responses include the following:

\section{Induced histological defense}

After the establishment of infection in plant cells, the host defense system tries to create barriers to prevent the pathogen to colonize of other tissues. This may be at various levels such as: Lignifications, Suberization, Abscission layers, Tyloses [8-11].

\section{Induced cellular defense}

There are different types of cellular defense structures such as changes in cell walls which play a limited role in defense. Such observable changes in cell wall structures include; synthesis of secondary wall and papillae formation, callose deposition, structural proteins, induced cytoplasmic defense that present last line of host defense which may be effective against slow growing pathogens, weak parasites or some symbiotic relationship [12].

\section{Induced biochemical changes}

The induced biochemical changes in host plants are the last line of host defense. This limit either the plant is susceptible or resistant to the pathogen. The role of biochemical factors in host defense is based on four main attributes which include:

A. Association of the substance protection against disease at the site where protection occurs.

B. Isolation of the substance from the host showing protection against the disease.

C. Conferment of protection by the isolated substance when introduction into to the appropriate susceptible host.

Similarity of the nature of protection induced to the natural agents of a resistant plant [11].

\section{References}

1. Friedt W, Sowdon RJ (2009) Oilseed rape. In: Vollmann J, Rajcan I (Eds.), Handbook of plant breeding. Oil crops, Springer, New York, USA, pp. 91126.

2. Walker KC, Booth EJ (2001) Agricultural aspects of rape and other Brassica products. Eur J Lipid Sci Technol 103(7): 441-446.

3. Wittkop B, Snowdon RJ, Friedt W (2009) Status and perspectives of breeding for enhanced yield and quality of oilseed crops for Europe. Euphytica 170: 131-140.

4. Szydłowska CA, Bartkowiak BI, Karlović I, Karlovits G, Szłyk E (2011) Antooxidant capacity, total phenolics, glucosinolates and colour parameters of rapeseed cultivars. Food Chem 127(2): 556-563.

5. Howell PM, Sharpe AG, Lydiate DJ (2003) Homoeologous loci control the accumulation of seed glucosinolates in oilseed rape (Brassica napus). Genome 46(3): 454-460.

6. Uzunowa M, Ecke W, Weissleder K, Röbbelen G (1995) Mapping the genome of rapeseed (Brassica napus L.) I. Construction of an RFLP linkage map and localization of QTLs for seed glucosinolate content. Theor Appl Genet 90(2): 194-204.

7. Würschum T, Liu WX, Maurer HP, Abel S, Reif JC (2012) Dissecting the genetic architecture of agronomic traits in multiple segregating population in rapeseed (Brassica napus L.). Theor Appl Genet 124(1): 153-161.

8. Poplawska W, Bartkowiak Broda I, Szala L (2007) Genetic and breeding evaluation of doubled haploid lines with restorer gene for CMS ogura system of winter oilseed rape (Brassica napus L.). Brassica 9(1-4): 29-32.

9. Bocianowski J, Kozak M, Liersch A, Bartkowiak BI (2011) A heuristic method of searching for interesting markers in terms of quantitative traits. Euphytica 181(1): 89-100.

10. Wielebski F (2006) Sulphur fertilization of different types of winter oilseed rape varieties in various soil conditions. II. Effects on quality and chemical composition of seeds. Rośliny Oleiste-Oilseed Crops, XXVII, 2: 283-297.

11. Liersch A, Bocianowski J, Bartkowiak Broda I (2013) Fatty acid and glucosinolate level in seeds of different types of winter oilseed rape cultivars (Brassica napus L.). Communications in Biometry and Crop Science 8(2): 39-47. 
12. Gollob HF (1968) A statistical model which combines features of factor analytic and analysis of variance techniques. Psychometrika 33(1): 73155.

13. Gauch HG (1988) Model selection and validation for yield trials with interaction. Biometrics 44(3): 705-715.

14. Nowosad K, Liersch A, Popławska W, Bocianowski J (2016) Genotype by environment interaction for seed yield in rapeseed (Brassica napus L.) using additive main effects and multiplicative interaction model. Euphytica 208(1): 187-194.

15. Bocianowski J, Nowosad K, Liersch A, Popławska W, Łącka A (2018) Genotype-by-environment interaction for seed glucosinolate content in winter oilseed rape (Brassica napus L.) using an additive main effects and multiplicative interaction model. Biometr. Lett 55(1): 85-96.

16. Gauch HG (1992) Statistical analysis of regional yield trials: AMMI analysis of factorial designs. Elsevier, New York, USA, p. 278.

17. Nowosad K, Liersch A, Poplawska W, Bocianowski J (2017) Genotype by environment interaction for oil content in winter oilseed rape (Brassica napus L.) using additive main effects and multiplicative interaction model. Indian J Genet Pl Br 77(2): 293-297.

18. Purchase JL, Hatting H, van Deventer CS (2000) Genotype $\times$ environment interaction of winter wheat (Triticum aestivum L.) in South Africa: II. Stability analysis of yield performance. South Afric J Plant Soil 17(3): 101-107.

19. Wang Y, Mette MF, Miedaner T, Wilde P, Reif JC, et al. (2015) First insights into the genotype-phenotype map of phenotypic stability in rye. J Exp Bot 66(11): 3275-3284.
20. Sang JP, Minchinton IR, Johnstone PK, Truscott RJW (1984) Glucosinolate profiles in the seed, root and leaf tissue of cabbage, mustard, rapeseed, radish and swede. Can J Plant Sci 64(1): 77-93.

21. Magrath R, Herron C, Giamoustaris A, Mithen R (1993) The inheritance of aliphatic glucosinolates in Brassica napus. Plant Breeding 111(1): 5572.

22. Mithen R (2001) Glucosinolates-biochemistry, genetics and biological activity. Plant Growth Regulation 34(1): 90-103.

23. Liersch A (2006) Influence of genetic variability on heterosis effect in winter oilseed rape (Brassica napus L.). PhD dissertation. Plant Breeding and Acclimatization Institute, Poznań, Poland.

24. Ishida M, Hara M, Fukino N, Kakizaki T, Morimitsu Y (2014) Glucosinolate metabolism, functionality and breeding for the improvement of Brassicaceae vegetables. Breed Sci 64(1): 48-59.

25. Charron CS, Sams CE (2004) Glucosinolate content and myrosinase activity in rapid-cycling Brassica oleracea grown in a controlled environment. J Amer Soc Hort Sci 129(3): 321-330.

26. Chen B, Xu K, Li H, Gao G (2018) Evaluation of quality traits and their genetic variation in global collections of Brassica napus L. Plant Genet Resour 16(2): 146-155.

27. Jensen CR, Mogensen VO, Mortensen G, Fieldsend JK, Milford GFJ, et al. (1996) Seed glucosinolate, oil and protein contents on field-grown rape (Brassica napus L.) affected by soil drying and evaporative demand. Field Crops Res 47(2-3): 93-105.

28. (1999) Seeds of oilseed rape. Determination of the glucosinolate content. Method using high performance liquid chromatography. 